\title{
PROFIL GIZI DAN KANDUNGAN KOLESTEROL UDANG WINDU (Penaeus monodon) DENGAN METODE PEMASAKAN BERBEDA
}

\author{
Ikbal Syukroni, Andi Santi* \\ ${ }^{1}$ Prodi Teknologi Pengolahan Hasil Perikanan, Politeknik Pertanian Negeri Pangkajene Kepulauan \\ Diterima: 3 September 2021/Disetujui: 28 Oktober 2021 \\ *Korespondensi: andisanti.polipangkep@gmail.com
}

Cara sitasi: Syukroni I, Santi A. 2021. Profil gizi dan kandungan kolesterol udang windu (Penaeus monodon) dengan metode pemasakan berbeda. Jurnal Pengolahan Hasil Perikanan Indonesia. 24(3): 319-324.

\begin{abstract}
Abstrak
Udang windu (Penaeus monodon) merupakan salah satu udang konsumsi yang nilai ekonomisnya terus meningkat dan banyak dikonsumsi oleh masyarakat. Penelitian ini bertujuan menentukan profil kandungan gizi dan kolesterol udang windu dengan perlakuan metode pemasakan berbeda yaitu perebusan, pengukusan, dan deep frying masing masing selama 10 menit, udang windu segar digunakan sebagai kontrol. Hasil penelitian menunjukan bahwa udang windu yang diberi pemasakan dengan perebusan kecenderungan perubahan nilai gizi tidak jauh berbeda dengan kontrol yaitu kadar air 71,93\%, kadar abu 3,25\%, kadar protein $18,82 \%$ dan kadar lemak 2,07\%. Pengolahan udang windu dengan metode pengukusan menunjukan nilai kolesterol yang rendah yaitu 1,69 mg/100 g. Berdasarkan hasil penelitian dapat disimpulkan bahwa proses pengolahan seperti perebusan, pengukusan, dan penggorengan metode deep frying mempunyai pengaruh terhadap profil gizi udang windu. Metode pengolahan pengukusan dapat mereduksi kandungan kolesterol pada udang windu sebanyak 94,12\%.
\end{abstract}

Kata kunci: deep frying, kolesterol, perebusan, pengukusan, udang windu

\section{Chemical and Cholesterol Content of Tiger Shrimp (Penaeus monodon) with Different Cooking Methods}

\begin{abstract}
Tiger shrimp (Penaeus monodon) is one of the consumption shrimp whose economic value continues to increase and is widely consumed by the community. This research aimed to determine the effect of chemical and cholesterol content of tiger shrimp with different cooking methods which is boiling, steaming and deep frying for 10 minutes each, fresh tiger prawns were used as control. The results showed that tiger shrimp that were given cooking with boiling tended to change the chemical content which was not much different from the control, moisture $71.93 \%$, ash $3.25 \%$, protein $18.82 \%$ and lipid $2.07 \%$. Processing of tiger shrimp using the steaming method showed a low cholesterol value of $1.69 \mathrm{mg} / 100 \mathrm{gr}$. Based on the results of the study, it can be concluded that processing processes such as boiling, steaming and deep frying method have an influence on the chemical content of tiger shrimp. Steaming processing method can reduce cholesterol content in tiger prawns as much as $94.12 \%$.
\end{abstract}

Keyword: boiling, cholesterol, deep frying, steaming, tiger shrimp 


\section{PENDAHULUAN}

Pengolahan bahan pangan merupakan pengubahan bentuk asli ke dalam bentuk yang mendekati bentuk produk dapat segera dimakan. Salah satu proses pengolahan bahan pangan adalah menggunakan pemanasan. Pengolahan pangan dengan menggunakan pemanasan dikenal dengan proses pemasakan yaitu proses pemanasan bahan pangan dengan suhu $100^{\circ} \mathrm{C}$ atau lebih dengan tujuan utama memperoleh rasa yang lebih enak, aroma yang lebih baik, tekstur yang lebih lunak, membunuh mikroba dan menginaktifkan semua enzim.

Pemasakan dapat dilakukan dengan perebusan dan pengukusan (boiling dan steaming pada suhu $100{ }^{\circ} \mathrm{C}$ ), pemanggangan (roasting) dan penggorengan dengan minyak (frying) dengan suhu antara $150-300{ }^{\circ} \mathrm{C}$. Penggunaan panas dalam proses pemasakan sangat berpengaruh pada nilai gizi bahan pangan tersebut.

Bahan pangan yang mengalami proses pemasakan akan terdegradasi kandungan gizinya. Tingkat penurunan gizi dipengaruhi suhu yang digunakan serta lamanya waktu proses pengolahan. Tinggi suhu yang digunakan dalam pengolahan akan sebanding dengan tingkat degradasi kandungan gizi. Beberapa penelitian sebelumnya tentang pengaruh suhu terhadap komposisi kimia akibat perlakuan suhu tinggi antara lain perebusan udang vannamei

(Bhat et al. 2017), proses pengukusan rajungan (Jacoeb et al. 2012), pengukusan kakap merah (Jacoeb et al. 2013), perebusan kerang pokea (Yenni et al. 2012), dan proses penggorengan pada ikan cakalang (Nurjanah et al. 2015).

Udang windu (Penaeus monodon) merupakan salah satu komoditas ekspor dari sektor perikanan unggulan di Indonesia. Udang windu merupakan salah satu udang konsumsi yang nilai ekonomisnya terus meningkat dan banyak dikonsumsi oleh masyarakat. Total produksi udang Indonesia tahun 2018 mencapai 400.073 ton, ekspor udang mencapai 150.000 ton pada tahun 2015 dan terus meningkat hingga tahun 2018, ekspor udang mencapai 170.000 ton (KKP 2018).
Efek dari proses pengolahan dengan pemberian panas pada udang putih akan memengaruhi komposisi kimia udang termasuk kadar lemak dan kolesterol. Pengetahuan tentang perubahan profil gizi dan kandungan kolesterol yang terjadi pada udang windu akibat proses pengolahan perlu diketahui. Salah satu perlakuan yang dapat dilakukan adalah dengan melakukan penelitian mengenai profil kandungan gizi dan kolesterol pada daging udang windu sebagai pengaruh beberapa pengolahan misalnya perebusan, pengukusan, dan penggorengan. Penelitian ini diharapkan dapat memberikan informasi yang berguna mengenai kandungan gizi udang windu kepada masyarakat. Tujuan dari penelitian ini adalah untuk menentukan pengaruh metode pemasakan yang berbeda yaitu perebusan, pengukusan, dan penggorengan terhadap perubahan kandungan gizi dan kolesterol pada udang windu.

\section{BAHAN DAN METODE Bahan dan Alat}

Bahan baku utama yang digunakan dalam penelitian ini adalah udang windu segar, minyak goreng (Bimoli). Bahan yang digunakan dalam penelitian ini adalah akuades, $\mathrm{H}_{2} \mathrm{SO}_{4}$ (Merck), $\mathrm{HCl} 0,02 \mathrm{~N}$ (Merck), $\mathrm{K}_{2} \mathrm{SO}_{4}$ (Merck), $\mathrm{HgO}, \mathrm{NaOH} 40 \%$ dan asetat anhidrid.

Alat-alat yang digunakan untuk proses pengolahan dalam penelitian ini adalah oven, desikator, tabung Kjedhal, labu destilat, tabung kondensor, Erlenmeyer, kertas saring, labulemak, tabung sentrifuge, alat pengaduk, beaker glass, penangas air, pipet tetes, cup sampel dan alat penguji kolesterol Automatic Analyzer (Biosystem A15).

\section{Metode \\ Penelitian pendahuluan}

Uji pendahuluan dilakukan untuk mengetahui penyusutan (cooking loss) udang windu setelah diberi perlakuan metode pemasakan yang berbeda. Perhitungan penyusutan dihitung dengan perbandingan berat udang windu setelah pemasakan dengan metode berbeda (Ovissipour et al. 2013) 


\section{Penelitian utama}

Udang windu segar masing-masing ditimbang dan diukur panjangnya. Selanjutnya terdapat empat perlakuan yang akan dilakukan pada daging udang windu yaitu perebusan, pengukusan, dan penggorengan metode deep frying selama 10 menit.

\section{Analisis proksimat}

Udang yang telah mengalami perlakuan dilakukan analisis kadar air (AOAC 2005), kadar protein (AOAC 2005), kadar lemak (AOAC 2005) dan kadar abu (AOAC 2005) yang dilakukan pada kondisi segar dan setelah proses perebusan, pengukusan, serta penggorengan metode deep frying. Analisis kadar air diukur menggunakan metode gravimetri, prinsip analisis kadar air adalah proses penguapan air dari suatu bahan dengan cara pemanasan, penentuan kadar air didasarkan pada perbedaan berat sampel sebelum dan sesudah dikeringkan. Analisis kadar lemak diukur menggunakan metode soxhlet. Prinsip analisis kadar lemak adalah ekstraksi yaitu pemisahan lemak dari sampel dengan cara pelarut lemak disirkulasikan ke dalam sampel, sehingga senyawa-senyawa lain tidak dapat larut dalam pelarut tersebut. Analisis protein total diukur menggunakan metode Kjehdahl, Prinsip analisis kadar protein adalah proses pembebasan nitrogen dari protein dalam bahan menggunakan asam sulfat dengan pemanasan. Analisis kadar abu menggunakan metode dekstruksi. Prinsip analisis kadar abu adalah proses pembakaran senyawa organik sehingga didapatkan residu anorganik yang disebut abu.

\section{Pengujian kolesterol}

Pengujian kolesterol pada udang windu yang telah dilakukan berbagai jenis pengolahan berdasarkan Pires et al. (2018) yang dimodifikasi. Sampel udang ditimbang sebanyak $2 \mathrm{~g}$ dalam tabung reaksi dengan tutup berlapis. Etanol $8 \mathrm{~mL}$ yang mengandung $0,25 \%$ butil hidroksil anisol (BHA) dan larutan $\mathrm{KOH}$ ditambahkan dalam air. Selanjutnya disaponifikasi pada suhu $80{ }^{\circ} \mathrm{C}$ selama 15 menit, dikocok (digoyang-goyangkan) selama pemanasan.Sampel didinginkan dengan air, kemudian ditambahkan $15 \mathrm{~mL}$ sikloheksana dan akuades $12 \mathrm{~mL}$, lalu dikocok dengan vortex selama 1 menit. Setelah itu sampel disentrifugasi selama 5 menit pada kecepatan $5.000 \mathrm{rpm}$ sampai terbentuk serum. Selanjutnya serum yang terbentuk kemudian dipipet sebanyak $1.000 \mu \mathrm{L}$, kemudian dimasukkan ke cup sampel dan telah siap untuk diperiksa. Tahapan akhir, sample dimasukkan di alat Automatic Analyzer Biosystem A15, setelah 15 menit nilai kolesterol akan terbaca.

\section{HASIL DAN PEMBAHASAN Susut Masak (Cooking Loss)}

Susut masak merupakan berat yang hilang selama pemasakan yang dipengaruhi oleh suhu dan waktu pemasakan. Udang windu yang digunakan pada penelitian ini memiliki susut masak yang berbeda berdasarkan perlakuan preparasi dalam keadaan segar dan preparasi setelah perebusan, pengukusan, dan penggorengan. Susut masak udang berupa daging, kepala, dan cangkang. Nilai susut masak udang windu segar dan setelah berbagai proses pengolahan dapat dilihat pada Figure 1.

Hasil penelitian menunjukkan bahwa susut masak udang windu segar berbeda dengan susut masak udang windu yang diberi perlakuan. Nilai rendemen pada udang windu yang diberi perlakuan rebus $79,44 \%$ menyebabkan terjadinya penyusutan atau kehilangan berat $20,56 \%$. Udang windu yang diberi perlakuan kukus memiliki rendemen $81,32 \%$ menyebabkan penyusutan $18,68 \%$. Udang windu yang diberi perlakuan penggorengan memiliki rendemen 82,41\% menyebabkan penyusutan $17,59 \%$.

Penyusutan berat pada udangwindu setelah pemasakan berkaitan dengan berkurangnya kadar air pada bahan. Erdogdu et al. (2004) menjelaskan bahwa dengan bertambahnya waktu pemanasan saat pemasakan pada suhu diatas $90^{\circ} \mathrm{C}$ dan waktu pemasakan diatas tiga menit susut masak pada bahan akan tinggi.

Denaturasi protein seperti protein miofibril dan kolagen dengan proses pemanasan adalah faktor yang menyebabkan kehilangan air. Selain itu, selama proses termal, penyusutan dan pengerasan jaringan otot menghasilkan peningkatan tekanan internal, 


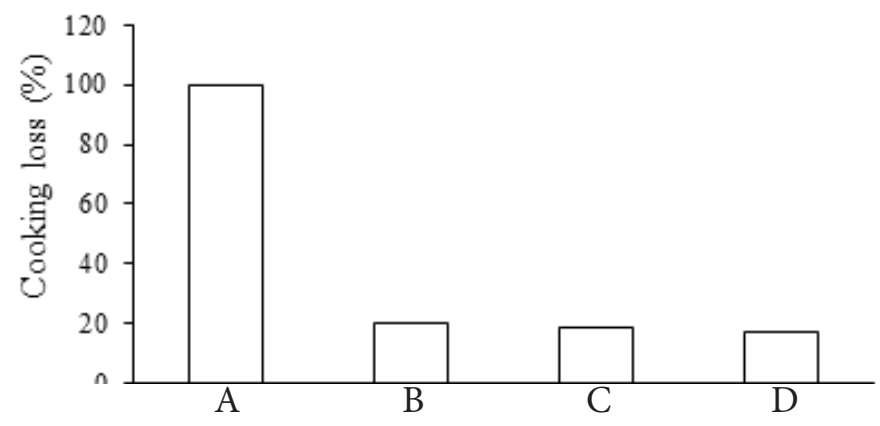

Figure 1 Cooking loss of tiger shrimp in various cooking methods; (A) Fresh/Control; (B) Boiled; (C) Steamed; (D) Deep fried

yang selanjutnya menyebabkan pelepasan air dari jaringan daging. Akibatnya, berat udang menurun setelah mengalami proses termal (Ovissipour et al. 2013)

\section{Komposisi Kimia}

Kandungan air dalam pangan merupakan salah satu komponen penting karena dapat memengaruhi penampakan dan tekstur serta mutu. Jumlah kadar air pada udang windu merupakan komponen kimia yang terbesar. Kadar air udang windu segar dan setelah berbagai proses pengolahan dapat dilihat pada Table 1.

Hasil uji pengukuran kadar air menunjukkan bahwa kadar air udang windu segar $(72,59 \%)$ berbeda dengan kadar air udang windu yang direbus (71,93\%), dikukus (70,33\%), dan digoreng (61,78\%). Penurunan kadar air disebabkan oleh faktor pengolahan dengan panas. Pemanasan adalah metode pengolahan yang menyebabkan kehilangan air cukup tinggi pada daging. Jacoeb et al. (2008) menyatakan bahwa pengolahan dengan panas pada suhu $100{ }^{\circ} \mathrm{C}$ mengakibatkan air dari dalam daging akan keluar, hal inilah yang menyebabkan kadar air setelah pengolahan mengalami penurunan.

Kadar abu suatu bahan pangan menunjukkan jumlah mineral yang terdapat dalam bahan pangan tersebut dan juga sebagai salah satu penentu parameter nilai gizi suatu bahan makanan. Kadar abu udang windu segar dan setelah berbagai proses pengolahan dapat dilihat pada Table 1. Hasil pengukuran kadar abu menunjukkan bahwa kadar abu udang windu segar $(3,43 \%)$ tidak jauh berbeda dengan kadar abu udang windu yang diberi perlakuan perebusan $(3,25 \%)$, pengukusan (3,24\%), dan penggorengan $(3,02 \%)$.

Purwaningsih et al. (2013) menyatakan bahwa daging keong kukus dan daging keong rebus memiliki kadar abu yang tidak berbeda. Hal ini bisa disebabkan kandungan mineral yang ada di dalam daging keong cukup mantap saat dilakukan proses perebusan dan pengukusan. Penelitian Abraha et al. (2008) menunjukkan bahwa perubahan komposisi mineral pada saat pemasakan dapat diakibatkan terlarutnya sejumlah mineral ke dalam air perebusan selama proses perebusan berlangsung. Walau demikian penurunan yang terjadi tidak terlalu besar karena pengolahan yang dilakukan hanya selama 10 menit. Penurunan kadar abu ini mungkin akan semakin besar seiring dengan lama proses perebusan yang berlangsung.

Hasil uji pengukuran kadar protein (Table 1) menunjukkan bahwa kadar protein udang windu segar (20,09\%) berbeda dengan kadar

Table 1 Chemical content of tiger shrimp in various cooking methods

\begin{tabular}{lrrrr}
\hline Parameter (\%) & Fresh (Control) & \multicolumn{1}{c}{ Boiled } & Steamed & Deep Fried \\
\hline Moisture & 72.59 & 71.93 & 70.33 & 61.78 \\
Ash & 3.43 & 3.25 & 3.24 & 3.02 \\
Protein & 20.09 & 18.82 & 18.17 & 24.51 \\
Lipid & 2.68 & 2.07 & 1.29 & 3.74 \\
\hline
\end{tabular}


protein udang windu yang diberi perlakuan perebusan $(18,82 \%)$, pengukusan $(18,17 \%)$, dan penggorengan (24,51\%).

Udang windu yang telah melalui proses penggorengan memiliki kandungan air yang lebih kecil dibandingkan saat daging masih segar dan proses pemasakan lainnya sehingga menyebabkan persentasi protein udang windu dengan proses deep frying meningkat. Penelitian Utami et al. (2016) menemukan bahwa kandungan protein ikan seluang goreng lebih tinggi dibandingkan dengan ikan seluang segar. Hal ini dapat dipengaruhi oleh rendahnya kandungan kadar air pada ikan seluang goreng.

Hasil uji pengukuran kadar lemak udang windu (Table 1) menunjukkan bahwa kadar lemak udang windu segar $(2,68 \%)$ berbeda dengan kadar lemak udang windu yang diberi perlakuan perebusan $(2,07 \%)$, pengukusan $(1,29 \%)$, dan penggorengan $(3,74 \%)$.

Meningkatnya kadar lemak pada udang windu yang digoreng disebabkan oleh proses penggorengan yang dilakukan. Utami et al. (2016) menyatakan bahwa meningkatnya kadar lemak ikan seluang goreng karena banyaknya ruang kosong pada tubuh ikan yang digoreng sehingga diisi oleh minyak akibat suhu dan lamanya waktu penggorengan.

\section{Kadar Kolesterol}

Lemak hewani mengandung banyak sterol yang disebut kolesterol. Kolesterol adalah parameter yang paling untuk diketahui. Jenis udang windu diduga memiliki kadar kolesterol yang tinggi. Hasil dari analisis kadar kolesterol berdasarkan metode proses pemasakan yaitu segar, rebus, kukus dan deep frying dapat dilihat pada Figure 2.
Hasil uji pengukuran kandungan kolesterol menunjukkan bahwa kandungan kolesterol udang windu pada perlakuan segar $17,41 \mathrm{mg} / 100 \mathrm{~g}$, direbus $7,01 \mathrm{mg} / 100 \mathrm{~g}$, dikukus $1,69 \mathrm{mg} / 100 \mathrm{~g}$, dan digoreng 28,78 $\mathrm{mg} / 100 \mathrm{~g}$.

Selama proses pengolahan, terjadi perubahan terhadap komponen lemak, yaitu asam lemak dan kadar kolesterol udang windu melalui proses hidrolisis. Pengolahan yang dilakukan dengan cara dikukus memiliki kadar kolesterol lebih rendah daripada dimasak dengan cara direbus dan digoreng. Hal ini disebabkan pada proses pengukusan pengurangan kadar air sangat tinggi sehingga kolesterol larut bersamaan dengan terlepasnya air dari bahan pangan (Riyanto et al. 2007).

\section{KESIMPULAN}

Berdasarkan hasil penelitian dapat disimpulkan bahawa proses pengolahan berupa perebusan, pengukusan, dan penggorengan metode deep frying mempunyai pengaruh terhadap profil gizi udang windu. Pengolahan dengan metode pengukusan mempunyai nilai kolesterol yang rendah yaitu $1,69 \mathrm{mg} / 100 \mathrm{~g}$ pada udang windu, sehingga dapat disimpulkan bahwa metode pengolahan pengukusan dapat mereduksi kandungan kolesterol pada udang windu sebanyak $94,12 \%$.

\section{UCAPAN TERIMA KASIH}

Terima kasih diucapkan kepada Kementerian Pendidikan, Kebudayaan, Riset dan Teknologi yang telah mendanai pelaksanaan penelitian ini melalui skema penelitian PNBP nomor 043/PL.22.7.1/SPPG/2021

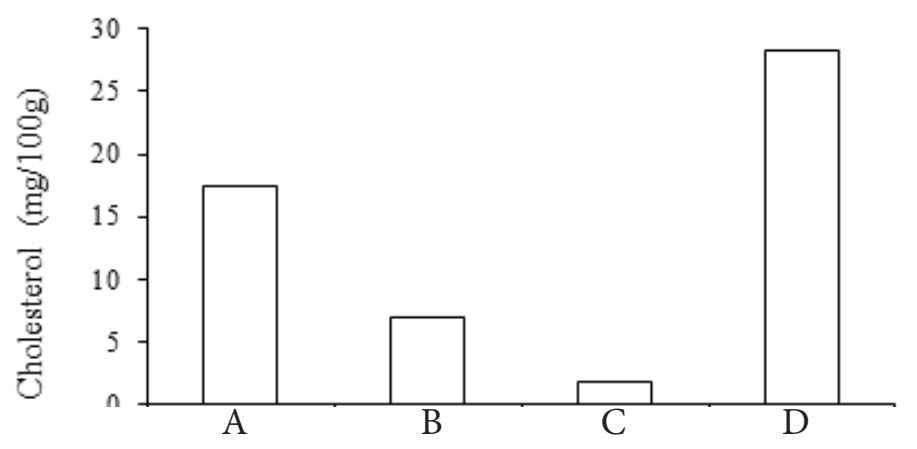

Figure 2 Cholesterol content of tiger shrimp in various cooking methods; (A) Fresh/Control; (B) Boiled; (C) Steamed; (D) Deep fried 


\section{DAFTAR PUSTAKA}

[AOAC] Association of Official Analytical Chemist. 2005. Official Method of Analysis of The Association of Official Analytical of Chemist. Arlington (US)

Abraha B, Admassu H, Mahmud A, Tsighe N, Shui XW, Fang Y. 2018. Effect of processing methods on nutritional and physico-chemical composition of fish: a review. MOJ Food Processing \& Technology. 6(4): 376-382.

Bhat TH, Chouksey MK, Balange SK, Nayak BB. 2017. Effect of heat treatment at different stages of rigor on the quality of pacific white shrimp (Litopenaeus vannamei). Journal of Aquatic Food Product Technology. 26(7): 770-780.

Erdogdu F, Balaban MO, Otwell WS, Laura G. 2004. Cook-related yield loss for pacific white (Penaeus vannamei) shrimp previously treated with phosphates: effects of shrimp size and internal temperature distribution. Journal of Food Engineering. 64: 297-300.

Jacoeb AM, Hamdani M, Nurjanah. 2008. Perubahan komposisi kimia dan vitamin daging udang ronggeng (Harpiosquilla raphidea) akibat perebusan. Buletin Teknologi Hasil Perikanan. 11(2): 76-88.

Jacoeb AM, Nurjanah, Lingga LA Br. 2012. Karakteristik protein dan asam amino daging rajungan (Portunus pelagicus) akibat pengukusan. Jurnal Pengolahan Hasil Perikanan Indonesia. 15(2):156-163.

Jacoeb AM, Nurjanah, Saraswati A. 2013. Kandungan asam lemak dan kolesterol kakap merah (Lutjanus bohar) setelah pengukusan. Jurnal Pengolahan Hasil Perikanan Indonesia. 16(2): 168-176.
Hwang CC, Lin CS, Lee YC, Wei CI, Tung HN, Ou TY, Chen TY, Tsai YH. 2021. Physicochemical and microbial quality of prepackaged shrimp processed by a scaled up microwave-assisted induction heating technology. Applied Science. 11: 9514.

Nurjanah, Suseno SH, Hidayat T, Paramudhita PS, Ekawati Y, Arifanto TB. 2015. Changes in nutritional composition of skipjack (Katsuwonus pelamis) due to frying process. International Food Research Journal. 22(5): 2093-2102.

Pires, DR, de Morais CAN, Coelho CCS, Marinho AF, Góes LC. Pires DSA, Augusta IM, Ferreira FS, Saldanha T. 2018. Nutritional composition, fatty acids and cholesterol levels in Atlantic white shrimp (Litopenaeus schimitti). International Food Research Journal. 25(1): $151-157$.

Purwaningsih S, Salamah E, Apriyana GP. 2013. Profil protein dan asam amino keong ipong-ipong (Fasciolaria salmo) pada pengolahan yang berbeda. Jurnal Gizi Dan Pangan. 8(1): 77-82.

Riyanto R, Priyantono N, Siregar T. 2007. Pengaruh perebusan, penggaraman dan penjemuran pada udang dan cumi terhadap pembentukan 7-ketokolesterol. Jurnal Pasca Panen dan Bioteknologi Kelautan dan Perikanan. 2(2): 147-151.

Utami P, Lestari S, Lestari SD. 2016. Pengaruh metode pemasakan terhadap komposisi kimia dan asam amino ikan seluang (Rasbora argyrotaenia). FishtecH - Jurnal Teknologi Hasil Perikanan. 5(1): 73-84. 